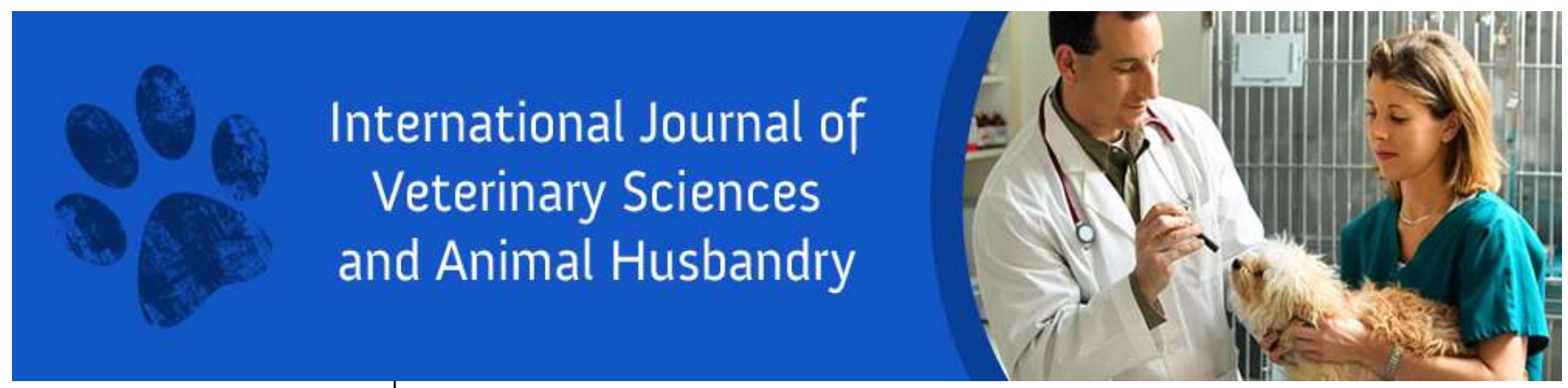

ISSN: 2456-2912

VET 2021; 6(1): 15-18

(C) $2021 \mathrm{VET}$

www.veterinarypaper.com

Received: 10-11-2020

Accepted: 12-12-2020

Hristina Neshovska

University of Forestry, Faculty of Veterinary Medicine, Sofia, Bulgaria

\section{Iliyan Manev}

University of Forestry, Faculty of Veterinary Medicine, Sofia,

Bulgaria

\section{Veselin Kirov}

University of Forestry, Faculty of Veterinary Medicine, Sofia, Bulgaria
Corresponding Author: Hristina Neshovska University of Forestry, Faculty of Veterinary Medicine, Sofia, Bulgaria

\section{Heavy metal levels in water, brown algae (Cystoseira barbata), and eelgrass (Zostera marina) from the Southern Black Sea coast of Bulgaria}

\author{
Hristina Neshovska, Iliyan Manev and Veselin Kirov
}

DOI: https://doi.org/10.22271/veterinary.2021.v6.i1a.317

\section{Abstract}

The heavy metals concentration in algae and marine water can be used as a bioindicator of an ecosystem pollution. In the present study, we determined the levels of the elements $\mathrm{As}, \mathrm{Pb}, \mathrm{Cd}, \mathrm{Hg}, \mathrm{Mn}, \mathrm{Zn}$, and $\mathrm{Al}$ in brown algae of the species Cystoseira barbata (Agardh, 1820), eelgrass Zostera marina (Linnaeus, 1753 ) and also in cold seawater. The samples were collected during the summer period of 2020 from the region of the Southern Bulgarian Black Sea coast. Our results showed low levels of heavy metals in seawater and much higher in the studied plant species, especially of aluminum in brown algae.

Keywords: Heavy metals, brown algae, eelgrass, seaweed, seawater, black sea

\section{Introduction}

Determination of heavy metal levels in marine flora and fauna can be used in the monitoring of biome pollution (Topcuoglu et al., 2010) ${ }^{[21]}$. Marine algae belong to the group of primitive non-flowering photosynthetic macrophytes and their habitat are the seas and oceans. Algae and seaweed can be used as a reliable indicator of chemical pollution status due to their ability to bioaccumulate heavy metals (Jordanova et al. 1999; Strezov and Nonova 2003; Abdallah et al., 2005; Strezov and Nonova 2005; Alkhalifa, 2012; Culha et al., 2013, Ali et al., 2017) ${ }^{[1,2,3 \text {, }}$ $7,18,19]$. Lewis and Devereux (2008) ${ }^{[12]}$ pointed to the eelgrass of the species Zostera marina as one of the most suitable species as a bioindicator of pollution. In addition, the same authors observed a characteristic periodicity and seasonality in the heavy metal level in algae. The element absorption by aquatic plants is a part of their biological cycle (Strezov and Nonova, 2005) ${ }^{[19]}$. According to Jordanova et al. (1999) ${ }^{[10]}$ the content of chemical elements in seawater and in the aquatic inhabitants can severely vary. Significantly lower concentrations were observed in seawater compared to flora and fauna samples.

The Black Sea is a semi-enclosed type of sea basin, well isolated from the waters of the World ocean, but in a connection with most of the major European rivers (Stoichev et al., 2007) ${ }^{[17]}$. Based to this Black Sea is considered one of the most polluted seas, which in turn leads to a decline in the fishing and tourism industry (Mirinchev et al., 1999; Stancheva et al., 2014) [13, 16]. Jitar et al. (2013) ${ }^{[11]}$ concluded that heavy metals are one of the main pollutants in the Black Sea.

The aim of our study was to determine heavy metal levels (As, $\mathrm{Pb}, \mathrm{Cd}, \mathrm{Hg}, \mathrm{Mn}, \mathrm{Zn}$ and $\mathrm{Al}$ ) in brown algae of the species Cystoseira barbata, eelgrass Zostera marina and seawater from the Southern Black Sea region.

\section{Materials and Methods}

Algae and seawater samples were collected from the Southern Black Sea Coast area (Burgas region) during the summer of 2020. Samples of Cystoseira barbata and Zostera marina were collected from the shallow part of the seabed and from the coastline, carefully rinsed with seawater, and packed in plastic bags. They were stored at $-20{ }^{\circ} \mathrm{C}$ until analysis. Water samples were taken from the same area in 0.5-liter plastic bottles and stored in a refrigerated state at a temperature of 0 to $4{ }^{\circ} \mathrm{C}$ until the test, which was performed within 24 hours. 


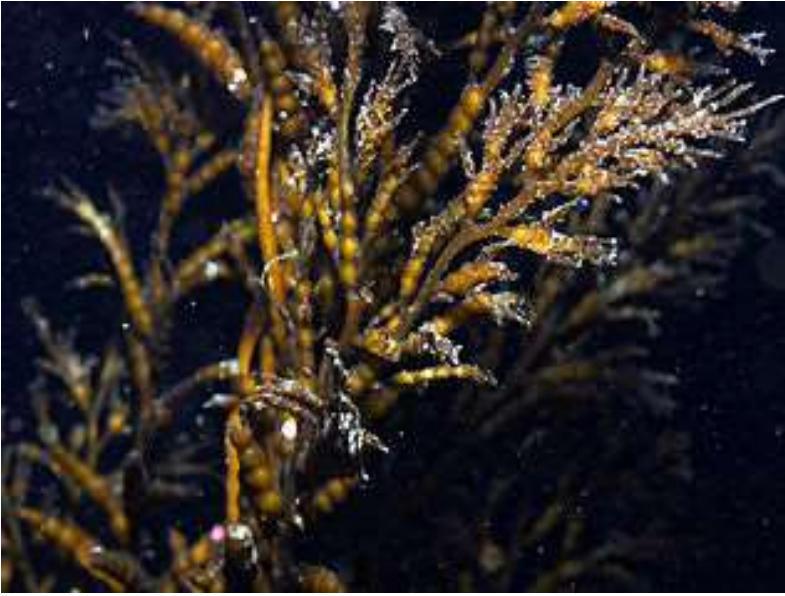

Cystoseira barbata

(https://en.wikipedia.org/wiki/Cystoseira)

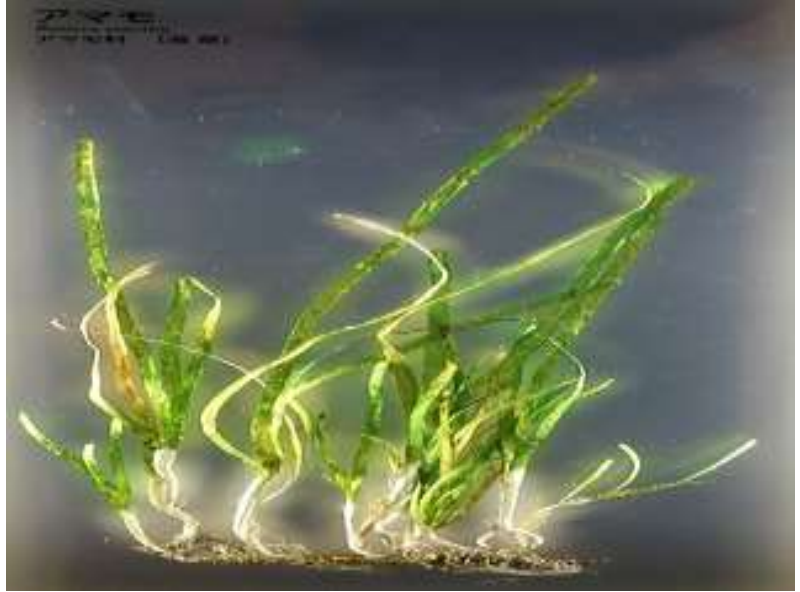

Zostera marina

(https://en.wikipedia.org/wiki/Zostera_marina\#/media/File:Zostera_marina__National_Museum_of_Nature_and_Science,_Tokyo_-_DSC07663.JPG)
The analysis of algae was carried out after homogenization (Vortex Homogenizer), followed by microwave assisted acid digestion procedure (ETHOS UP high-performance Microwave digestion system, Milestone Inc). After digestion with nitric acid an appropriate spectroscopy determination with inductively coupled plasma mass spectrometry (ICP-MS, Thermo Fisher TM) was performed. The summarized results of this study were presented as mean values $(\mathrm{X})(\mathrm{mg} / \mathrm{kg})$ weight- for algae and $(\mathrm{mg} / \mathrm{l})$ for water \pm standard deviation (SD). The data were subjected to a statistical analysis with Student's-test to estimate the significance of values ( $\mathrm{p}<$ $0.05)$.

\section{Results and Discussion}

The results of the tested metals in the seawater are presented in Table. 1 and of brown algae and seaweed are summarized in Table 3. The order of the levels of the heavy metal concentrations was $\mathrm{Al}=\mathrm{As}=\mathrm{Zn}>\mathrm{Pb}=\mathrm{Mn}>\mathrm{Cd}>\mathrm{Hg}$ for seawater, $\mathrm{Al}>\mathrm{As}>\mathrm{Mn}>\mathrm{Zn}>\mathrm{Pb}>\mathrm{Cd}>\mathrm{Hg}$ for Cystoseira barbata, $\mathrm{Al}>\mathrm{Mn}>\mathrm{As}>\mathrm{Zn}>\mathrm{Pb}>\mathrm{Cd}=\mathrm{Hg}$ for Zostera marina.

The data obtained in Tables 1 and 3 showed that heavy metal pollution of seawater is significantly lower than that of algae. This fact could be explained by the property of living organisms to bioaccumulate, which was confirmed by the results of Jordanova et al. (1999) ${ }^{[10]}$. In general, our results for arsenic, zinc and aluminum levels in seawater were lower than $0.05 \mathrm{mg} / \mathrm{l}$ and they were below the limit of detection.
The values for manganese and lead were $<0,01 \mathrm{mg} / \mathrm{l}$, and the lowest concentration was for the $\mathrm{Hg}(<0.001 \mathrm{mg} / \mathrm{l})$. The seawater levels for arsenic, zinc, lead, mercury, and cadmium were below the maximum permissible concentrations for the quality of the coastal waters, specified in Ordinance № 8 of 25.01.2001 ${ }^{[14]}$.

Table 1: Heavy metal concentrations $(\mathrm{mg} / \mathrm{l})$ in seawater from Southern Bulgarian Black Sea coast

\begin{tabular}{|c|c|c|}
\hline Element $(\mathbf{X} \pm$ SD) & Unit & Sea water \\
\hline $\mathrm{As}$ & $\mathrm{mg} / \mathrm{l}$ & $<0.05^{*}$ \\
\hline $\mathrm{Pb}$ & $\mathrm{mg} / \mathrm{l}$ & $<0.01^{*}$ \\
\hline $\mathrm{Cd}$ & $\mathrm{mg} / \mathrm{l}$ & $<0.005^{*}$ \\
\hline $\mathrm{Hg}$ & $\mathrm{mg} / \mathrm{l}$ & $<0.001^{*}$ \\
\hline $\mathrm{Mn}$ & $\mathrm{mg} / \mathrm{l}$ & $<0.01^{*}$ \\
\hline $\mathrm{Zn}$ & $\mathrm{mg} / \mathrm{l}$ & $<0.05^{*}$ \\
\hline $\mathrm{Al}$ & $\mathrm{mg} / \mathrm{l}$ & $<0.05^{*}$ \\
\hline
\end{tabular}

*Method detection limits

The results of Peycheva et al. (2016) ${ }^{[15]}$ (Table 2) showed significantly lower values of the studied elements compared to those obtained in the present study. At the same time the cadmium and mercury concentrations of Ukrainian sea water samples were with higher levels compared to the Bulgarian region (Dyatlov, 2015) ${ }^{[8]}$. The published values of Boran and Altinok (2010) ${ }^{[5]}$ from the Turkey coast were in accordance with the current data, with the exception for the higher levels of $\mathrm{Mn}(0.039281 \mathrm{mg} / \mathrm{l})$.

Table 2; Some heavy metal mean values in seawater from Black Sea coast (mg/l)

\begin{tabular}{|c|c|c|c|}
\hline Heavy metals (mg/kg) & Area & Water & Reference \\
\hline As & Bulgaria & 0.0011 & Peycheva et al. (2016) ${ }^{[15]}$ \\
\hline $\mathrm{Pb}$ & Bulgaria & 0.00034 & Peycheva et al. (2016) ${ }^{[15]}$ \\
\hline \multirow{2}{*}{$\mathrm{Cd}$} & Bulgaria & $<0.00005$ & Peycheva et al. (2016) ${ }^{[15]}$ \\
\hline & Ukraine & 0.23 & Dyatlov $(2015)^{[8]}$ \\
\hline $\mathrm{Hg}$ & Bulgaria & $<0.00005$ & Peycheva et al. (2016) ${ }^{[15]}$ \\
\hline $\mathrm{Mn}$ & Turkey & 0.039281 & Borat and Altinok (2010) ${ }^{[5]}$ \\
\hline \multirow{4}{*}{$\mathrm{Zn}$} & Bulgaria & 0.0005 & Peycheva et al. (2016) ${ }^{[15]}$ \\
\hline & Turkey & 0.054535 & Borat and Altinok (2010) ${ }^{[5]}$ \\
\hline & Bulgaria & 0.031 & Peycheva et al. (2016) ${ }^{[15]}$ \\
\hline & Ukraine & 7.20 & Dyatlov $(2015)^{[8]}$ \\
\hline
\end{tabular}

Heavy metal values in the table were recalculated from mcg/l.

Table 3 showed the results for the studied flora species. For both algae, the highest content was for aluminum - in Cystoseira barbata and Zostera marina - $574.36 \pm 114.87$ $\mathrm{mg} / \mathrm{kg}$ and $85.15 \pm 17.03 \mathrm{mg} / \mathrm{kg}$ respectively. We found high levels for both algae species in terms of Mn and As. We also obtained higher levels of zinc in brown algae compared to 
eelgrass. In both studied species the values for lead were similar, and those of mercury were below the detection limit $<0.05 \mathrm{mg} / \mathrm{kg}$. Data showed that Cystoseira barbata accumulated heavy metals in higher proportion compared to Zostera marina, with the exception of manganese, which was with $25.92 \%$ higher than in eelgrass. The present research for the Bulgarian region showed that brown algae bioaccumulated larger amounts of the studied chemical elements, with the exception of manganese, which makes them more sensitive pollution indicator than the sea water and seaweeds.

Table 3: Heavy metal concentrations ( $\mathrm{mg} / \mathrm{kg}$ weight) in algae from Southern Bulgarian Black Sea coast

\begin{tabular}{|c|c|c|c|}
\hline Element $(\mathbf{X} \pm$ SD) & Unit & Cystoseira barbata & Zostera marina \\
\hline $\mathrm{As}$ & $\mathrm{mg} / \mathrm{kg}$ & $28.37 \pm 5.67$ & $1.62 \pm 0.32$ \\
\hline $\mathrm{Pb}$ & $\mathrm{mg} / \mathrm{kg}$ & $0.35 \pm 0.07$ & $0.29 \pm 0.06$ \\
\hline $\mathrm{Cd}$ & $\mathrm{mg} / \mathrm{kg}$ & $0.14 \pm 0.03$ & $<0,05^{*}$ \\
\hline $\mathrm{Hg}$ & $\mathrm{mg} / \mathrm{kg}$ & $<0,05^{*}$ & $<0,05^{*}$ \\
\hline $\mathrm{Mn}$ & $\mathrm{mg} / \mathrm{kg}$ & $26.73 \pm 5.35$ & $33.66 \pm 6.73$ \\
\hline $\mathrm{Zn}$ & $\mathrm{mg} / \mathrm{kg}$ & $8.57 \pm 1.71$ & $1.06 \pm 0.21$ \\
\hline $\mathrm{Al}$ & $\mathrm{mg} / \mathrm{kg}$ & $574.36 \pm 114.87$ & $85.15 \pm 17.03$ \\
\hline
\end{tabular}

*Method detection limits

$* * p<0.05$

As could be seen from Table 4 heavy metal levels in brown algae were lower than the data presented by other authors, with the exception of Mn. Also, the level of zinc for the
Bulgarian region was lower compared to the levels obtained by Topcuoglu et al. (2001) ${ }^{[20]}$ and higher than the data of Cadar et al. (2018) ${ }^{[6]}$.

Table 4: Some heavy metal mean values in algae from Black Sea coast (mg/kg)

\begin{tabular}{|c|c|c|c|c|}
\hline \multirow{2}{*}{ Heavy metals } & \multirow{2}{*}{ Area } & \multicolumn{2}{|c|}{ Mean value } & \multirow{2}{*}{ Reference } \\
\hline & & Cystoseira barbata & Zostera marina & \\
\hline As & Turkey & & 2 & Arici and Bat. (2020) ${ }^{[4]}$ \\
\hline \multirow{5}{*}{$\mathrm{Pb}$} & Turkey & & 1.9 & Arici and Bat (2020) ${ }^{[4]}$ \\
\hline & Turkey & 1.0 & & Topcuoglu et al. (2001) ${ }^{[20]}$ \\
\hline & Turkey & & 1.17 & Tuncer and Yaramaz (1992) \\
\hline & Turkey & $3.51(2016)$ & & Cadar, E., et al. (2018) ${ }^{[6]}$ \\
\hline & Turkey & $5.51(2017)$ & & Cadar, E., et al. (2018) ${ }^{[6]}$ \\
\hline \multirow{5}{*}{$\mathrm{Cd}$} & Turkey & & 0.1 & Arici and Bat. (2020) ${ }^{[4]}$ \\
\hline & Turkey & 0.70 & & Topcuoglu et al. (2001) ${ }^{[20]}$ \\
\hline & Turkey & & 1.05 & Tuncer and Yaramaz (1992) \\
\hline & Turkey & $0.281(2016)$ & & Cadar et al. (2018) ${ }^{[6]}$ \\
\hline & Turkey & $0.330(2017)$ & & Cadar et al. (2018) ${ }^{[6]}$ \\
\hline $\mathrm{Hg}$ & Turkey & & 0.017 & Arici and Bat. (2020) ${ }^{[4]}$ \\
\hline \multirow{3}{*}{$\mathrm{Mn}$} & Turkey & & 761.8 & Arici and Bat. (2020) ${ }^{[4]}$ \\
\hline & Turkey & 23.8 & & Topcuoglu et al. (2001) ${ }^{[20]}$ \\
\hline & Turkey & & 138.8 & Tuncer and Yaramaz (1992) \\
\hline \multirow{5}{*}{$\mathrm{Zn}$} & Turkey & & 114.8 & Arici and Bat $(2020)^{[4]}$ \\
\hline & Turkey & 59.3 & & Topcuoglu et al. (2001) \\
\hline & Turkey & & 3.63 & Tuncer and Yaramaz (1992) ${ }^{[22]}$ \\
\hline & Turkey & $1.93(2016)$ & & Cadar et al. $(2018)^{[6]}$ \\
\hline & Turkey & $2.55(2017)$ & & Cadar et al. (2018) ${ }^{[6]}$ \\
\hline $\mathrm{Al}$ & Turkey & & 1847.4 & Arici and Bat (2020) ${ }^{[4]}$ \\
\hline
\end{tabular}

Heavy metal values in the table were recalculated from $\mathrm{mcg} / \mathrm{kg}$.

The established heavy metals in the current survey in Zostera marina were in discrepancy with Tuncer and Yaramaz (1992) ${ }^{[22]}$ and with Arici and Bat (2020) ${ }^{[4]}$ which reported higher values. The high levels of aluminum in algae obtained in the present study and also by Arici and Bat (2020) ${ }^{[4]}$ confirmed the claim of Gillmore (2014) ${ }^{[9]}$ that this element is one of the main pollutants in marine ecosystems.

\section{Conclusions}

Based on the current results we can conclude that the level of heavy metals in the sampling area was lower in the living environment - seawater, compared to the bioaccumulation in living organisms - plant species Cystoseira barbata and Zostera marina.

The heavy metal level was higher in brown algae compared to eelgrass (with the exception of manganese) which should be taken into account when assessing the bioindicative value of these species.

The current study can serve as a basis for further investigations on heavy metal pollution in various levels of the Black sea ecosystems.

\section{Acknowledgements}

The current study is a part of Scientific Project of University of Forestry "Heavy metals bioaccumulation in hydrobionts", grant number NIS-B 1076/2020.

\section{References}

1. Abdallah AMA, Abdallah MA, Beltagy AI. Contents of heavy metals in marine seaweeds from the Egyptian coast of the Red Sea, Chemistry and Ecology 2005;21(5):399411, DOI: $10.1080 / 02757540500290222$ 
2. Ali AYA, Idris AM, Ebrahim AM, Eltayeb M. Brown algae (Phaeophyta) for monitoring heavy metals at the Sudanese Red Sea coast. Appl Water Sci 2017;7:38173824. https://doi.org/10.1007/s13201-017-0529-1

3. Alkhalifa AH, Al-Homaidan A, Ibrahim SS. Brown macroalgae as bio- indicators for heavy metals pollution of Al-Jubail coastal area of Saudi Arabia. African Journal of Biotechnology 2012;11(92):15888-15895. doi: 10.5897/AJB12.2509.

4. Arici E, Bat. Sediment-water interactions with eelgrass (Zostera spp.) from Sinop shores of the Black Sea. Caspian J. Environ. Sci 2020. 10.22124/CJES.2020.4039.

5. Boran M, Altinok I. A Review of Heavy Metals in Water, Sediment and Living Organisms in the Black Sea. Turkish Journal of Fisheries and Aquatic Sciences 2010. 10. 565-572. 10.4194/trjfas.2010.0418.

6. Cadar E, Mustafa A, Tomescu A, Cherim M. Studies regarding polluting agents in Black Sea algae. Journal of Science and Arts 2018;18(1):255-264, ISSN: 1844-9581

7. Culha T, Kocbas F, Gundogdu A., Culha M. 2013. Heavy metal levels in marine algae from the Black Sea, Marmara Sea and Mediterranean Sea. 10.13140/2.1.1182.9123.

8. Dyatlov S. 2015. Heavy Metals in Water and Bottom Sediments of Odessa Region of the Black Sea, Journal of Shipping and Ocean Engineering 2015;5:51-58, DOI:10.17265/2159-5879/2015.02.001

9. Gillmore M. Theses: Toxicity of aluminium in seawater: diatom sensitivity. University of Wollongong. Research Online Faculty of Science, Medicine \& Health - Honours Theses University of Wollongong Thesis Collections 2014.

10. Jordanova A, Strezov A, Ayranov M, Petkov N, Stoilova T. Heavy metal assessment in algae, sediments and water from the Bulgarian Black Sea coast. Water Science and Technology - Water Sci Technol 1999;39:207-212. 10.1016/S0273-1223(99)00204-8.

11. Jitar O, Teodosiu C, Nicoara M, Plavan G. Study of heavy metal pollution and bioaccumulation In the Black Sea living environment. Environmental Engineering and Management Journal., February 2013;12(2):271-276.

12. Lewis M, Devereux R. Nonnutrient anthropogenic chemicals in seagrass ecosystems: Fate and effects. Environmental toxicology and chemistry / SETAC 2008. 28. 644-61. 10.1897/08-201.1.

13. Mirinchev GA, Tzankov Tz V, Kostova IS, Mirincheva MG. Impact of Bulgarian rivers on heavy metal pollution of the black sea, Water Science and Technology 1999;39(8):9-12, ISSN 0273-1223, https://doi.org/10.1016/S0273-1223(99)00181-X.

14. Ordinance No. 8 of January 25 , on the quality of coastal seawaters 2001.

15. Peycheva K, Stancheva M, Georgieva S, Makedosnki L. Heavy metals in water, sediments and marine fishes from Bulgarian Black Sea // Materials of XXVI International Coastal Conference "Managing risks to coastal regions and communities in a changing world". Academus Publishing 2021,

$1-1$. https://doi.org/10.31519/conferencearticle_5b1b93d4d78 bb6.88545986.

16. Stancheva M, Makedonski L, Peycheva K. Determination of heavy metal concentrations of most consumed fish species from Bulgarian Black Sea coast Bulgarian Chemical Communications 2014;46(1):195-203.
17. Stoichev T, Makedonski L, Trifonova T, Stancheva M, Ribarova F. DDT in fish from the Bulgarian region of the Black Sea, Chemistry and Ecology 2007;23(3):191-2000.

18. Strezov A, Nonova T. Monitoring of $\mathrm{Fe}, \mathrm{Mn}, \mathrm{Cu}, \mathrm{Pb}$ and Cd levels in two brown macroalgae from the Bulgarian Black Sea coast. International Journal of Environmental Analytical Chemistry - Int J Environ Anal Chem 2003. 83. 1045-1054. 10.1080/03067310310001621042.

19. Strezov A, Nonova T. Comparative analysis of heavy metal and radionuclide contaminants in Black Sea green and red macroalgae. Environmental Monitoring and Assessment July 2005. DOI: 10.1007/s10661-005-31583.

20. Topcuoglu S, Guven K, Kirbasoglu C, Unlu S, Yilmaz Y. Heavy metals in marine algae from Sile in the Black Sea 2001, 1994-1997. Bulletin of environmental contamination and toxicology 67:288-94.

21. Topcuoglu S, Kilic O, Belivermis M, Aytekin Ergul H, Kalayci G. Use of marine algae as biological indicator of heavy metal pollution in Turkish marine environment $\mathrm{J}$. Black Sea/Mediterranean Environment 2010;16(1):43-52.

22. Tuncer S, Yaramaz O. Heavy metals and other elements in Zostera marina L. on the Trabzon Coast Line (Black Sea; Turkey) Rapp. Comrn. Int. Mer Medit 1992; 33. 